Edukids volume 17 (1) tahun 2020

EDUKIDS: Jurnal Pertumbuhan, Perkembangan, dan Pendidikan Anak Usia Dini

Jln. Dr. Setiabudhi No. 229 Kota Bandung 40154. e-mail: edukid@upi.edu

website: http://ejournal.upi.edu/index.php/edukid

\title{
PENDIDIKAN KARAKTER ANAK USIA DINI PADA KELUARGA TANPA AYAH
}

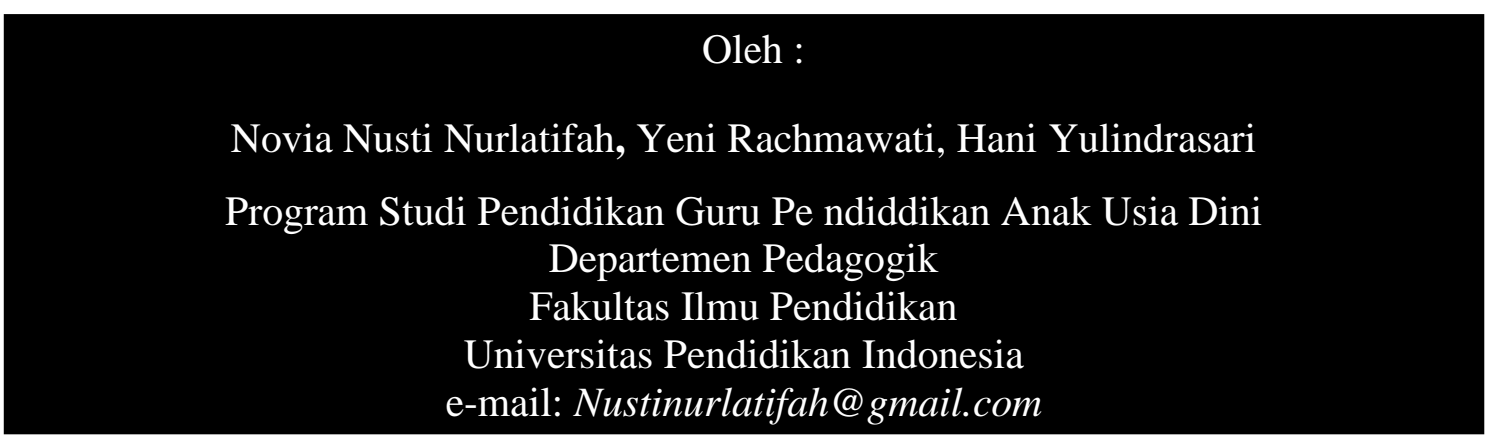

Abstrak : Penelitian ini menganalisis pendidikan karakter anak usia dini yang hidup dengan orang tua tunggal, dalam penelitian ini konteks orang tua tunggal adalah keluarga tanpa ayah. Ketidakhadiran ayah dalam penelitian ini karena perceraian. Dimana ayahnya masih hidup, tetapi tidak berperan dalam pengasuhan. Penelitian ini menggunakan pendekatan studi kasus untuk memperoleh gambaran menyeluruh dan pemahaman terbaik mengenai tema tersebut. Pendekatan studi kasus ini digunakan oleh peneliti dilatarbelakangi karena maraknya kasus perceraian, yang mengakibatkan anak kehilangan salah satu peran orang tua. Orang tua menanamkan pendidikan karakter pada anak melalui contoh dan pembiasaan serta pemberian penjelasan atas tindakan. Dalam praktek pendidikan karakter dalam keluarga tanpa ayah, ibu melibatkan pihak lain, seperti kakek-nenek dan ustadz. Kendala yang dialami ibu dalam menjalankan peran sebaga ibu dan ayah yaitu pembagian waktu dan masalah finansial. Karakter anak yang terbentuk dari pendidikan dalam keluarga tanpa ayah ini yaitu anak yang mandiri, tidak manja, dan penurut.

\section{Kata kunci : kelurga, pendidikan karakter, tanpa ayah}

Abstract : This study analyzes how early childhood character education lives with single parents, in this study the context of a single parent is a family without a father. Father's absence in this study was due to divorce. Where his father is still alive, but does not play a role in nurture. This study uses a case study approach to obtain a comprehensive picture and the best understanding of the theme. This case study approach is used by researchers because of the rise in divorce cases, which results in the child losing one of the roles of parents. The parents instill character education in children through examples and habituation and providing explanations for actions. In the practice of character education in families without fathers, mothers involve other parties, such as grandparents and Ustadz. Constraints experienced by mothers in carrying out the role as mothers and fathers, namely the division of time and financial problems. The character of the child formed from education in a family without a father is an independent child, not spoiled, and obedient.

Key words : family, character education, without father. 


\section{PENDAHULUAN}

Karakter adalah seluruh kebaikan yang membentuk kualitas mental atau moral, kekuatan moral, dan reputasi seseorang yang tidak diwariskan namun dibangun secara berkesinambungan hari demi hari, sehingga memfokuskan tingkah laku orang tersebut dalam mengaplikasikan nilai kebaikan (Andrianto, 2011; Lickona 2012). Menurut Amirulloh (2015) istilah karakter erat kaitannya dengan kepribadian seseorang, dimana individu dapat dikatakan orang yang berkarakter (a person of character) jika tingkah lakunya sesuai dengan kaidah moral.

Pendidikan karakter dinilai sangat penting untuk dimulai pada anak usia dini karena pendidikan karakter adalah proses pendidikan yang ditujukan untuk mengembangkan sikap, nilai, dan perilaku yang memancarkan akhlak mulia atau budi pekerti luhur terutama didasarkan pada agama yang baik oleh orang tuanya. Menurut Darajat (1997:71) terdapat tiga lingkungan yang bertanggung jawab dalam mendidik karakter anak yaitu, keluarga, sekolah, dan masyarakat. Dari ketiganya, lingkungan keluarga memiliki tanggung jawab utama terhadap pendidikan karakter anak.

Dalam prespektif islam, keluarga merupakan tempat yang strategis dalam pembinaan karakter anak. Baik-buruknya karakter anak sangat bergantung pada baikburuknya pendidikan dalam keluarga. Amirulloh (2015) berpendapat bahwa keluarga adalah lingkungan utama yang dapat membentuk watak dan karakter anak. Keluarga adalah lingkungan pertama tempat anak sosialisasi dengan manuisa lain selain dirinya. Keluarga sebagai institusi pendidikan dan keagamaan, merupakan lingkungan pendidikan pertama anak sebelum ia melangkah kepada lembaga pendidikan lain. Dalam keluargalah seorang anak akan dibentuk watak, budi pekerti, dan kepribadiannya.
Tidak dapat dipungkiri bahwa keluarga memiliki peran yang begitu besar dalam pembentukan karakter anak usia dini, juga sebagai media sosialisasi terbaik dalam pendidikan moral bagi anak. Akan tetapi, saat ini struktur keluarga telah berubah. Salah satunya adalah disebabkan oleh perceraian. Data dari Dirjen badan Peradilan Agama, Mahkamah Agung pada periode 2014-2016 perceraian Indonesia trennya meningkat. Dari 344.237 perceraian pada tahun 2014 , naik menjadi 365.633 perceraian di tahun 2016. Rata-rata angka perceraian naik 3 persen setiap tahunnya (Statistik Indonesia 2019, BPS). Di Amerika kebanyakan yang menjadi orang tua tunggal dan bertanggung jawab terhadap anaknya yaitu pihak perempuan (Lickona, 2012).

Sama seperti di Amerika, di Indonesia orang tua tunggal yang bertanggung jawab atas pengasuhan anak adalah perempuan. Negara mengatur pengasuhan anak dalam tiga peraturan. Bagi yang beragama islam jika terjadi pereceraian, pengaturan hak asuh anak diatur dalam pasal 105 Kompilasi Hukum Islam yang menyatakan :

"Dalam hal terjadinya perceraian :

a. Pemeliharaan anak yang belum mumayyiz atau belum berumur 12 tahun adalah hak ibunya;

b. Pemeliharaan anak yang sudah mumayyiz diserahkan kepada anak untuk memilih diantara ayah dan ibunya sebagai pemegang hak pemeliharaanya;

c. Biaya pemeliharaan ditanggung oleh ayahnya."

Sementara bagi yang beragama non-islam, dasar hukum tentang hak pengasuhan anak jika terjadi perecaraian merujuk pada Yurisprudensi (putusan pengadilan terdahulu), sebagai berikut :

1. Putusan Mahkamah Agung RI No. 126 K/Pdt/2001 tanggal 28 Agustus 2003 dinyatakan bahwa : 
“..Bila terjadi perceraian, anak yang masih di bawah umur pemeliharaannya seyogiyanya diserahkan kepada orang terdekat dan akrab dengan si anak yaitu ibu.."

2. Putusan Mahkamah Agung RI No. 102 K/Sip/1973 tanggal 24 April 1975, menyatakan :

"Berdasarkan Yurisprudensi mengenai perwalian anak, patokannya ialah bahwa ibu kandung yang diutamakan, khususnya bagi anak-anak yang masih kecil, karena kepentingan anak yang menjadi kriterium, kecuali kalau terbukti bahwa ibu tersebut tidaj wajar untuk memelihara anaknya."

Penelitian tentang orang tua tunggal sudah banyak dilakukan dalam konteks negara barat. Banyak penelitian yang menunjukan ketidakhadiran ayah memiliki dampak negatif, contohnya yaitu penelitian yang dilakukan oleh Stephen \& Udisi (2016) dan Guardia, nelson, \& lertora (2014). Dampak negatif yang dipaparkan yaitu anak cenderung mengalami masalah sosial, psikologis, pendidikan, hingga masalah perilaku (Stephen \& Udisi, 2016). Selain itu disebutkan juga dampak negatif ketidakhadiran ayah berpengaruh pada hubungan seksual pertama anak dalam keluarga orangtua tunggal (Guardia, nelson, \& lertora, 2014)

Namun ada juga penelitian lain yang menyimpulkan bahwa ketidakhadiran ayah dalam keluarga tidak memberikan pengaruh kepada perkembangan anak yaitu penelitian yang dilakukan oleh Golombok, Tasker, \& Murray (1997) dan juga penelitian MacCallum \& Golombok (2004). Konteks keluarga tanpa ayah dalam penelitian diatas yaitu keluarga tanpa ayah sejak anak masih bayi. Sehingga ayah tidak pernah hadir dalam hidupnya. Jadi tidak ada dampak negatif terhadap perkembangan anak (Golombok, Tasker, \& Murray, 1997). Meskipun tidak ada dampak negatif, ketidakhadiran ayah menyebabkan anak laki-laki lebih menunjukkan sisi feminim, walaupun femininitas tersebut tidak mengurangi maskulinitasnya atau tidak mempengaruhi identitas gender dan identitas seksualnya (MacCallum \& Golombok, 2004).

Penelitian tentang orang tua tunggal di Indonesia masih sangat jarang. Ada penelitian dari Akbar (2015) dengan subjek penelitiannya yaitu remaja di kota Bandung. Penelitian ini menyimpulkan bahwa orang tua tunggal memberikan dampak negatif terhadap perkembangan anak. Anak yang berasal dari keluarga tunggal cenderung melakukan tindakan yang melanggar aturan yang dapat mengakibatkan kerugian terhadap dirinya sendiri maupun orang lain ketika usia remaja. Selain itu Fitroh (2014) melakukan penelitian tentang dampak ketidak hadiran ayah terhadap prestasi belajar anak. Penelitian tersebut menyimpulkan bahwa ketidakhadiran ayah berpengatuh terhadap prestasi belajar anak karena kehadiran ayah memberikan motivasi belajar kepada anak. Penelitian ini menggunakan metode studi literatur.

Penelitian yang menfokuskan pada keluarga tanpa ayah yang melihat dampaknya pada anak usia dini masih sulit ditemukan. Sehingga penelitian ini akan menganalisis bagaimana pendidikan karakter anak usia dini yang hidup dengan orang tua tunggal, dalam penelitian ini konteks orang tua tunggal adalah keluarga tanpa ayah. Ketidakhadiran ayah dalam penelitian ini karena perceraian. Dimana ayahnya masih hidup, tetapi tidak berperan dalam pengasuhan

\section{METODE}

Desain penelitian yang digunakan dalam penelitian ini adalah menggunakan jenis penelitian studi kasus. Menurut Sugiyono (2012, hlm. 14) menyatakan bahwa studi kasus merupakan salah satu jenis penelitian kualitatif, dimana peneliti melakukan eksplorasi secara mendalam terhadap program, kejadian, proses, aktivitas, terhadap satu atau lebih orang. Seperti yang diungkapkan Sarosa (2012, 
hlm 114) bahwa pemilihan studi kasus diawali dengan menemukan kasus yang menarik, dalam hal ini kedekatan peneliti; pengetahuan peneliti yang mendalam; dan ketertarikan peneliti terhadap suatu kasus merupakan kriteria pemilihan yang baik.

Alasan peneliti menggunakan pendekatan kualitatif dengan desain penelitian studi kasus, karena peneliti ingin meneliti secara mendalam tentang pendidikan karakter anak usia dini pada keluarga tanpa ayah.

Partisipan dalam penelitian ini yaitu empat responden yang terdiri dari orangtua tunggal (ibu) yang memiliki anak usia dini. Latar belakang menjadi orang tua tunggal dikarenakan perceraian. Penelitian ini dilakukan selama kurang lebih tujuh bulan mulai dari persiapan, tahap wawancara, dan analisis sampai pada pelaporan.

\section{HASIL DAN PEMBAHASAN}

Peneliti ingin memaparkan bahwasanya peran ayah dan ibu sangatlah berpengaruh terhadap pendidikan karakter anak di dalam keluarga, sehingga peneliti ingin memberikan gambaran terkait pandangan $\mathrm{ibu}$ tunggal mengenai pendidikan karakter anak pada keluarga tanpa ayah.

Bagian ini menguraikan temuan dan hasil wawancara peneliti di lapangan dengan empat partisipan. Temuan dan pembahasan dari data yang sudah dikumpulkan kemudian dianalisis dan dilakukan pengkategorisasian tema. Temuan yang ada kemudian dianalisis menggunakan teori.

\section{Pelaksanaan pendidikan karakter pada anak yang dilakukan oleh ibu tunggal}

Pada pembahasan ini, peneliti meyakini bahwa karakteristik anak juga dipengaruhi oleh kehadiran peran ayah. akan tetapi pada kenyataan dilapangan saat wawancara, responden memiliki pendapat yang berbeda-beda. Ada yang meyakini bahwa kehadiran peran ayah dalam pendidikan karakter anak dirumah tidak berpengaruh papda karakter yang terbentuk, namun ada pula yang berpendapat bahwa kehadiran ayah berpengaruh terhadap karakter anaknya.

Responden memahami bahwa karakteristik anak usia dini adalah meniru, oleh sebab itu pendidikan yang dilakukan dirumah yaitu dengan memberikan contoh dengan sikap dan perilaku yang baik, pembiasaan, serta diikuti dengan nasihat. Sejalan dengan pendapat Amini (2008) bahwa dalam rangka mengembangkan karakter yang baik pada anak harus menggunakan bahasa karakter. Dimana ayah-ibu perlu menjelaskan pada anak tentang perbuatan yang boeh dan tidak boleh dilakukan berikut alasannya dan tidak mendidik karakter melalui kata-kata saja.

Dalam pelaksanaan pendidikan karakter di keluarga tanpa ayah ini, ibu harus mengisi dua peran sekaligus menjadi ayah bagi anaknya. Untuk mengisi kekosongan peran ayah, ibu melakukan berbagai cara agar pendidikan karakter dirumah tidak pincang. Salah satu caranya yaitu dengan melibatkan pihak lain, seperti ustad, kakek, dan nenek. Responden meyakini bahwa dengan diajarkan ilmu agama, karakter anak yang terbetuk akan baik. namun dalam pelaksanaan responden hanya berperan sebagai pemberi dorongan pada anak, selebihnya dilimpahkan kepada guru ngaji. Selain itu menurut Suwito (Zubaedi, 2015) proses pendidikan karakter anak pada lingkungan keluarga juga tidak dapat mengabaikan peran kakek - nenek. Mereka memiliki peran vital dalam kehidupan cucu. Peran kakek dan nenek terhadap kehidupan cucu dilaksanakan dengan menjalankan tugas-tugas instrumental dan simbolik, mencakup semua bantuan praktis seperti; pemeliharaan anak, dukungan finansial, dan (dalam beberapa kasus) perumahan. Berkaitan dengan pengembangan karakter anak, semua anggota keluarga dapat memberikan pengaruh yang berarti.

\section{Kendala Pendidikan Karakter di Keluarga Tanpa Ayah}


Pendidikan karakter pada anak dikeluarga tanpa ayah dirasakan oleh ibu memiliki tantangan tersendiri, hal yang cukup menonjol yaitu kesulitan dalam membagi waktu antara mencari nafkah dan mendidik anak, kekhawatiran finansial karena sudah tidak diberi nafkah oleh mantan suami, ketergantungan anak pada gadget, serta berbagai tantangan lain terkait pendidikan karakter anak di keluarga.

Hasil dari wawancara yang dilakukan, kendala yang sangat dirasakan sebagai ibu tunggal adalah waktu dan masalah finansial. Ketidakhadiran peran ayah dalam keluarga membuat ibu harus memenuhi tugas sebagai ibu dan ayah bagi anaknya. Meskipun pada kenyataannya anak memerlukan figur ibu dan ayah secara komplementatif bagi perkembangan karakternya. Hal ini karena ada peran-peran ayah yang khas yang sulit tergantikan oleh ibu. Hal ini juga menjadi tantangan bagi narasumber, karena tidak semua peran dapat terpenuhi dalam satu waktu. Tidak tersedianya waktu yang cukup untuk bersama anak membuat kualitas hubungan pun menjadi kurang baik. yang dirasakan oleh responden bahwa kelekatan anatara ia dan anaknya menjadi sedikit berkurang. Responden merasa karena disibukkan dengan tugas mencari nafkah, ia menjadi kurang dekat dengan anaknya bahkan jika anaknya nangis yang dicari adalah nenek bukan dirinya. Hal ini menjadi tantangan untuk responden bagaimana caranya supaya kelekatan antara ia dan anaknya dapat tercipta kembali.

Selain masalah pembagian waktu, masalah lain yang sangat di rasakan setelah bercerai yaitu finansial. Kondisi sosial ekonomi keluarga berperan penting dalam pola pikir orang tua dalam menerapkan pola asuh bagi anaknya. Ketidakhadiran peran ayah dalam keluarga, menjadikan ibu sebagai tulang punggung keluarga. Ibu harus mencari nafkah untuk menghidupi anak-anaknya. Tidak adanya nafkah dari mantan suami diakarenakan hubungan yang kurang baik setelah bercerai mengharuskan ibu untuk bekerja. Selain masalah pembagian waktu, kekhawatiran finansial menjadi tantangan utama partisipan dalam membesarkan anaknya. Finansial dirasakan menjadi hambatan, ketika ibu juga mengemban tugas sebagai tulang punggung keluarga, keharusan mencari nafkas membuat ibu menjadi kurang dekat dengan anaknya karena waktu yang dihabiskan bersama menjadi lebih sedikit. Berbeda dengan narasumber yang kebutuhan hidupnya masih ditanggung oleh orang tuanya, finansial tidak menjadi masalah. Karena ia tidak perlu repot mencari nafkah dan tetap masih bisa menghabiskan waktu bersama anaknya.

\section{Pengaruh ketidakhadiran peran ayah dalam pembentukan karakter anak}

Peran utama pendidikan karakter terletak pada ayah dan ibu. Menurut Gunadi (Zubaedi, 2015) ada tiga peran utama yang dapat dilakukan ayah-ibu dalam mengembangkan karakter anak. Pertama, berkewajiban menciptakan suasana yang hangat dan tentram. Kedua, menjadi panutan yang positif bagi anak sebab anak belajar dari apa yang dilihatnya, bukan dari apa yang didengarnya, sehingga orang tua harus menjadi panutan bagi anak-anaknya. Ketiga, mendidik anak, artinya mengajarkan karakter yang baik dan mendisiplinkan anak agar sesuai dengan apa yang telah diaharkan. Saat ini terjadi pergeseran konsep, dari pengasuhan motherhood menjadi parenthood. Dimana konsep ini menitikberatkan pada peran kedua orang tuanya yaitu ayah dan ibu. Namun bagaimana jika peran ayah tidak ada ? apakah berpengaruh pada perkembangan karakter anak ?

Peran ayah seharusnya dapat menjadi pelindung, penyokong materi dan model keteladanan bagi anak-anaknya. Idealnya, ayah dapat memberikan kenyamanan tempat tinggal dan keamanan dari bahaya yang mengancam secara fisik maupun psikologis (Helmawati, 2014). Dengan begitu perlindungan, jaminan finansial dan pemenuhan spiritual yang menyeluruh 
dapat menyentuh jiwa dan raga anak-anak serta seluruh anggota keluarga

Pada dasarnya ayah memiliki peran yang tidak dapat digantikan oleh ibu, karena baik anak laki-laki maupun anak perempuan memerlukan ayah untuk mendampingi tumbuh kembangnya. Pada keluarga tanpa ayah nilai-nilai karakter yang dididikkan pada anak-anaknya tidak begitu bervariatif seperti keluarga lengkap. Hal ini dikarenakan skala prioritas yang dipilih oleh orangtua dengan menyesuaikan kebutuhan. Pada keluarga ini, nilai kemandirian, ketabahan, tanggung jawab, dan kerja keras lebih diutamakan.

Sebagian narasumber sepakat bahwa peran ayah sangat penting bagi pendidikan karakter anak. Ayah mempunyai peran tersendri bagi kehidupan anaknya, seperti yang diungkapkan oleh narasumber tiga bahwa sikap ayah (karakter ayah) mempengaruhi karakter anaknya. Menurut Responden tiga sifat anak juga dipengaruhi oleh sifat ayahnya. Jika ayahn nya pemarah, maka akan memperlakukan anaknya dengan kasar maka karakter anak pun akan tercipta menjadi karakter yang keras. Kagan berpendapat, bahwa anak mewarisi karakter fisiologis tertentu yang mendorong mereka memiliki tempramen tertentu meskipun dengan pengalaman mereka dapat memodifikasi mereka sampai tingkat tertentu (Santrock, 2007, hlm. 49). Senada dengan pernyataan responden tiga, responden satu juga berpendapat bahwa sikap tegas ayah dirasa mampu membentuk sifat anak menjadi lebih penurut.

Namun tidak semua narasumber merasa bahwa kehadiran ayah berpengaruh terhadap pembentukan karakter anak. Seperti yang dikemukakan oleh narasumber empat, menuturkan bahwa ketidakhadiran peran ayah tidak berpengaruh dalam pembentukan karakter anak. Karena sejak bayi anaknya sudah terbiasa hidup hanya dengan ibunya. Narasumber menyimpulkan bahwa kehadiran ayah tidak mempengaruhi karakter yang terbentuk pada anak.

Dari keermpat narasumber, yang mengungkapkan bahwa kehadiran ayah berpengaruh terhadap perkembangan karakter anak yaitu dua narasumber. Dalam kasus ini, anak narasumber sempat mengenal ayah walaupun hanya sebentar. Dan dua narasumber lainnya berpendapat bahwa kehadiran ayah tidak berpengaruh terhadap karakter anak yang terbentuk, karena anak narasumber sudah ditinggalkan oleh ayah sejak masih bayi, sehingga belum sempat mengenal ayahnya. Hal ini sejalan dengan penelitian yang dilakukan oleh Golombok, Tasker, \& Murray (1997) serta penelitian MacCallum \& Golombok (2004) yang menyimpulkan bahwa tidak ada pengaruhnya kehadiran peran ayah terhadap perkembangan karakter anak dalam konteks anak tidak pernah mengenal ayah.

\section{Karakter anak usia dini yang terbentuk di keluarga tanpa ayah}

Coles menggambarkan, anak-anak yang baik adalah anak-anak yang terutama telah belajar menganggap serius gagasan dan hasrat untuk menjadi baik-hidup sesuai dengan hukum emas, hormat kepada orang lain, memiliki keterlibatan pikiran, hati, dan jiwa pada keluarga, tetangga, dan bangsanya. Dan telah pula belajar bahwa masalah kebaikan bukanlah sesuatu yang abstrak, melainkan sesuatu yang konkret dan harus diungkapkan: bagaimana mengubah omongan kebaikan menjadi tindakan, saat-saat meneguhkan kehadiran kebaikan dalam penghayatan hidup tertentu (Sukiyani \& Zamroni, 2018).

Penentu keberhasilan pendidikan karakter dalam keluarga adalah cara orang tua mendidik anak-anaknya. Orang tua harus memiliki kepedulian kepada diri sendiri untuk akhirnya menjadi lebih peduli kepada anak-anaknya. Orang tua yang tidak peduli pada dirinya sendiri, akan mendidik anaknya ketidakpedulian. Mereka mendidik tanpa kasih sayang hanya sekedar melakukan kewajiban. Anak-anak mereka akan seperti robot. Namun orang tua yang peduli pada dirinya sendiri akan peduli pada dirinya sendiri pula. Mereka akan mendidik dengan kehangatan dan penuh 
kasih sayang. Seperti yang diutarakan oleh Zubaedi (2015) karakter tidak hanya dipengaruhi oleh pola asuh orangtua melainkan juga dipengaruhi oleh lingkungan sekitarnya. Karakter seseorang tidak dapat diubah, namun lingkungan dapat menguatkan atau memperlemah karakter tersebut.

Dalam penelitian ini menurut keempat narasumber ditemukan bahwa anak yang tumbuh di keluarga tanpa ayah karakter anak yang terbentuk menjadi anak yang lebih mandiri, tidak manja, dan penurut. Namun tidak hanya karakter baik saja yang muncul pada anak yang tumbuh di keluarga tanpa ayah. Anak yang besar dikeluarga tanpa ayah terbentuk juga sifat yang kurang baik. anak menjadi pemalu, dan juga anak cenderung minder jika berada di tempat yang ramai.

\section{SIMPULAN}

Berdasarkan hasil penelitian yang diperoleh penulis, maka dapat disimpulkan bahwa pandangan keluarga terhadap pendidikan karakter dalam perkembangan anak dipengaruhi oleh harapan orang tua terhadap anaknya. Orang tua menanamkan pendidikan karakter pada anak melalui pengasuhan yang baik, mencontohkan perilaku dan pembiasaan, dan pemberian penjelasan atas tindakan. Orang tua membentuk hati nurani dan kebiasaan pada anak melalui nasihat, pemberian contoh dengan sikap dan perilaku, serta pembiasaan.

Dalam praktek pendidikan karakter dalam keluarga tanpa ayah orang tua melibatkan pihak lain, seperti kakek nenek dan ustadz. Kakek - nenek memiliki peran yang tidak kalah penting karena sebagian besar waktu anak dihabiskan dengan kakek dan nenek. Sehingga besar kecilnya karakter anak di keluarga tanpa ayah juga dipengaruhi oleh didikan kakek dan neneknya. Sedangkan untuk menanamkan nilai religius, orang tua memilih untuk melimpahkannya kepada ustadz atau guru ngaji. Peran orang tua hanya mengarahkan dan memberikan semangat agar anak mau pergi mengaji.

Dari hasil penelitian yang telah dilakukan dua narasumber menyimpulkan bahwa kehadiran peran ayah dianggap penting bagi pembentukan karakter anak. Ayah memiliki peran penting dalam melaksanakan pendidikan karakter pada anak. Menurut narasumber ada beberapa sifat anaknya yang mirip dengan ayahnya, karena sempat mengenal ayah walaupun sebentar. Sedangkan menurut dua narasumber lainnya, kehadiran peran ayah dalam keluarga tidak berpengaruh pada perkembangan karakter anaknya, karena anak tidak pernah mengenal ayahnya.

\section{DAFTAR RUJUKAN}

Akbar, B.T. (2015). Pengasuhan Single Parent pada Kasus Kenakalan Remaja. Naskah Publikasi.

Amini, Mukti. (2008). Pengasuhan Ayah Ibu yang Patut, Kunci Sukses Mengembangkan Karakter Anak. Yogyakarta: Tiara Wacana.

Amirulloh. (2015). Teori Pendidikan Karakter Remaja Dalam Keluarga. Bandung: Alfabeta, CV.

Andrianto, T. T. (2011). Mengembangkan Karakter Sukses Anak di Era Cyber. Jogjakarta: Ar-Ruzz Media.

Darajat, Z. (1997). Problema Remaja di Indonesia. Jakarta: Bulan Bintang

Direktorat Jendral Badan Peradilan Agama (Statistik Indonesia 2019, BPS)

Fitroh, Siti, F. (2014). Dampak Fatherless Terhadap Prestasi Belajar Anak Dampak Fatherless Terhadap Prestasi Belajar Anak. Jurnal PgPaud Trunojoyo. 1(2). 76-146

Golombok, Tasker, \& Murray. (1997). Children raised in fatherless families from infancy: family 
relationships and the socioemotional development of children of lesbian and single heterosexual mothers. $J$ Child Psychol Psychiatry. 38(7):783-91.

Guardia, A.C.La, dkk. (2014). The Impact of Father Absence on Daughter Sexual Development and Behaviors: Implication for Professional Counselors. The Family Journal: Counseling and Therapy for Couplex and Families, 22, (3), 339-346. Diakses dari: https://

journals.sagepub.com/doi/abs/10.1 177/10664807145229887?journal Code $=$ tfja [6 Oktober 2018]

Helmawati. (2014). Pendidikan Keluarga: Teoretis dan Praktis. Bandung: Remaja Rosdakarya Offset.

Kompilasi Hukum Islam Pasal 105. Diakses dari: https://hukum.unsrat.ac.id (Pdf) [12 Agustus 2019]

Lickona, T. (2012). Educating for Character: Mendidik untuk Membentuk Karakter. Jakarta: PT Bumi Aksara.

MacCallum \& Golombok (2004). families from infancy: a follow-up of children of lesbian and single heterosexual mothers at early adolescence. The Journal of Child Psychology and Psychiatry. 45(8). 1407-1419

Santrock, John W. (2007). Perkembangan Anak. Jilid 1 Edisi kesebelas. Jakarta : PT. Erlangga.

Sarosa, Samiaji. (2012) Penelitian Kualitatif: Dasar-dasar. Jakarta : PT Indeks.

Sugiyono. (2012). Metode Penelitian Pendidikan Pendekatan Kuantitatif,
Kualitatif, dan R\&D. Bandung: Alfabeta

Sukiyani, F \& Zamroni. (2018). Pendidikan Karakter dalam Lingkungan Keluarga. Jurnal Ilmu-Ilmu Sosial. 11(1). 57-70.

Stephen, E.N \& Lawrence U. (2016). Single Parent Families and Their Impact on Children: A Study of Amassoma Community in Bayelsa State. European Journal of Research in Social Sciences, 4, (9), 1-24. Diakses dari: http://www.idpublications.org/wp -content/uploads/2016/10/FullPaper-SINGLE-PARENTFAMILIES-AND-THEIRIMPACT-ON-CHILDREN-ASTUDY-OF-AMASSOMACOMMUNITY.pdf [3 Oktober 2018]

Zubaedi. (2015). Desain Pendidikan Karakter. Jakarta: Kencana Prenada Media Grup 